\title{
Serum concentration of 19 serum proteins in Crohn's disease and ulcerative colitis
}

\author{
B. WEEKE AND S. JARNUM
}

From Medical Department P, Division of Gastroenterology, Rigshospitalet, Copenhagen, and the Protein Laboratory, University of Copenhagen, Copenhagen, Denmark

SUMMARY The serum concentration of 19 serum proteins was determined by electrophoresis in 42 patients with Crohn's disease and 36 patients with ulcerative colitis. The results were compared with 78 healthy persons as matched controls. Distinctive, but similar, changes were present in the two diseases. An increased serum concentration of orosomucoid, $\alpha_{1}$-antitrypsin, easily precipitable glycoprotein, $\alpha_{1}$-antichymotrypsin, haptoglobin, and haemopexin was present. The serum concentration was decreased for prealbumin, albumin, $\alpha_{2}-\mathrm{HS}$ glycoprotein, caeruloplasmin, $\alpha_{2}$-macro-globulin, and transferrin. No significant difference between the two diseases existed as far as the serum protein pattern was concerned.

Certain proteins, 'the acute phase reactants' (orosomucoid, $\alpha_{1}$-antitrypsin, $\alpha_{1}$-antichymotrypsin, and haptoglobin) and the immunoglobulins were clinically useful, since their serum concentration reflected the grade of activity of the disease. A pronounced elevation of haptoglobin compared with that of the other 'acute phase reactants' was present in patients with Crohn's disease complicated by suppurative fistulas or abscesses. Patients with active Crohn's disease who responded favourably to medical treatment had significantly higher immunoglobulin levels than patients not responding. A similar observation, though not statistically significant, was made in patients with ulcerative colitis.

In paper electrophoretic studies of serum from patients with ulcerative colitis depressed albumin and increased $a_{2}$-globulin levels have been reported (Bicks, Kirsner, and Palmer, 1959a and b; de Dombal, 1968). Serum $\gamma$-globulin was elevated in the same series, but in other studies it was found to be normal (Soergel and Ingelfinger, 1961; de Dombal 1969). It has also been suggested that a raised $\gamma$-globulin concentration heralds a better prognosis for the individual patient on medical treatment (Bicks et al, 1959a and b; de Dombal, 1968).

Glycoprotein staining of the paper electrophoretic strip has revealed an increase of $a_{1}$ - and $a_{2}$-glycoproteins (Soergel and Ingelfinger, 1961). On chemical fractionation of serum proteins a seromucoid fraction can be obtained which consists predominantly of acid $a_{1}$-glycoprotein (orosomucoid). The concentration of this glycoprotein appears to be a valid indicator of the activity of Crohn's disease as well as of ulcerative colitis (Cooke, Fowler, Cox, Gaddie, and Meynell, 1958; Dearing, McGuckin, and Elveback, 1969).

Received for publication 9 December 1970.
Immunochemical quantitative analysis of albumin and immunoglobulins in Crohn's disease and ulcerative colitis indicates that essentially the same changes occur in the two diseases: hypoalbuminaemia, normal or elevated IgG concentration, and normal levels of IgA and IgM (Bendixen, Jarnum, Søltoft, Westergaard, Weeke, and Yssing, 1968; Bendixen, Goltermann, Jarnum, Jensen, Weeke, and Westergaard, 1970; Weeke and Bendixen, 1969).

In the present study 19 serum proteins were determined immunochemically in patients with Crohn's disease or ulcerative colitis. The results were compared in the two diseases and with matched controls. Also, the findings were related to clinical data and course, and a comparison was made with earlier results obtained by paper electrophoresis.

\section{Methods}

Nineteen serum proteins were determined by means of immunoelectrophoretic methods previously published (Weeke, 1968 and 1970). Serum albumin, IgG, 
IgA, and IgM were quantitated by electrophoresis of the serum proteins in agarose gel containing rabbit antihuman albumin, IgG, $\operatorname{IgM}^{1}$, or $\operatorname{IgA}^{2}$. The remaining 15 serum proteins were identified and quantitated by the Laurell crossed electrophoresis (Weeke, 1970) method using rabbit antihuman serum protein. ${ }^{1}$ The concentration of the individual serum proteins was expressed in arbitrary units using for reference a serum pool from 1,000 healthy blood donors. The concentration of 15 of the serum proteins could be expressed in grams per litre when the reference serum was compared with standard serum Op. 166. ${ }^{2}$

All sera examined had been stored at $-18^{\circ} \mathrm{C}$ with $1 \%$ sodium azid for less than one year during which only a slight fall in the concentration of the lipoproteins was observed.

Twelve serum proteins displayed a positively skew distribution of their concentrations, in both normal and pathological sera (Table I). However, the logarithm of the concentrations conformed to an almost Gaussian-like distribution. Consequently the logarithms were used for calculation of the mean

'Dakopatts, Brostex, 10, Overgaden oven Vandet, 1415 Copenhagen, Denmark.

'Behringwerke, Marburg/Lahn, Germany. and standard deviation, and for statistical evaluation of differences between populations according to Student's $t$ test.

\section{Case Material}

Seventy-eight patients were studied for three years. Diagnosis was based on clinical, radiological, sigmoidoscopic, and histological data. Crohn's disease was present in 42 (19 men and 23 women); 22 of these patients had been ill for less than two years and the remainder for up to 22 years. The mean age was 32 years, varying from 15 to 75 years. Twenty patients had been operated on before the study and after the study another six patients underwent surgery. The disease was quiescent in 10 , mild in 11 , moderate in 18 , and severe in three patients according to criteria for ulcerative colitis given by Dearing et al (1969). All severe cases had intraabdominal abscesses, several moderate cases had recurrent subilens (four cases), or suppurative anal fistulas with or without abscesses (five cases).

Ulcerative colitis was diagnosed in 36 patients ( 16 men and 20 women); in 19 the disease had been present for less than two years, and up to 17 years in the rest. The mean age was 35 years, varying from

\begin{tabular}{|c|c|c|c|c|c|}
\hline Serum Protein & Values & Log. Values Used & Crohn's Disease & Ulcerative Colitis & Controls \\
\hline Prealbumin & $\mathrm{g} / 1$ & No & $0.19^{1}(0 \cdot 03-0 \cdot 36)$ & $0 \cdot 17^{1}(0.06-0 \cdot 30)$ & $0.24(0.11-0.37)$ \\
\hline Albumin & $\mathrm{g} / \mathbf{l}$ & No & $35 \cdot 3^{1}(16 \cdot 5-54 \cdot 1)$ & $34 \cdot 6^{1}(16 \cdot 0-53 \cdot 2)$ & $45 \cdot 7(37 \cdot 7-53 \cdot 7)$ \\
\hline $\begin{array}{l}\text { Orosomucoid } \\
a_{1} \text {-lipoprotein } \\
a_{1} \text {-antitrypsin } \\
\text { Easily precipitable glycoprotein } \\
a_{1} \text {-antichymotrypsin }\end{array}$ & $\begin{array}{l}\mathrm{g} / 1 \\
\mathrm{au} / 1^{3} \\
\mathrm{~g} / 1 \\
\mathrm{au} / 1 \\
\mathrm{au} / 1\end{array}$ & $\begin{array}{l}\text { Yes } \\
\text { Yes } \\
\text { No } \\
\text { Yes } \\
\text { Yes }\end{array}$ & $\begin{array}{l}1 \cdot 49^{1}(0 \cdot 53-4 \cdot 19) \\
117(58-237) \\
2 \cdot 52^{1}(0 \cdot 91-4 \cdot 13) \\
115^{1}(66-200) \\
162^{1}(71-369)\end{array}$ & $\begin{array}{c}1 \cdot 66^{1}(0 \cdot 57-4 \cdot 86) \\
106(43-261) \\
2 \cdot 54^{1}(0 \cdot 79-4 \cdot 28) \\
117^{1}(66-207) \\
196^{1}(69-558)\end{array}$ & $\begin{array}{l}0.74(0 \cdot 44-1 \cdot 26) \\
111(58-211) \\
1 \cdot 62(1 \cdot 06-2 \cdot 17) \\
93(61-143) \\
108(71-163)\end{array}$ \\
\hline $\begin{array}{l}\text { Gc-protein } \\
a_{2} \text {-HS glycoprotein } \\
\text { Haptoglobin } \\
\text { Caeruloplasmin } \\
a_{2} \text {-Macroglobulin }\end{array}$ & $\begin{array}{l}\mathrm{g} / 1 \\
\mathrm{~g} / 1 \\
\mathrm{~g} / 1 \\
\mathrm{~g} / 1 \\
\mathrm{~g} / 1\end{array}$ & $\begin{array}{l}\text { No } \\
\text { No } \\
\text { Yes } \\
\text { Yes } \\
\text { No }\end{array}$ & $\begin{array}{l}0.30(0 \cdot 17-0 \cdot 43) \\
0 \cdot 48^{1}(0 \cdot 14-0 \cdot 82) \\
3 \cdot 39^{1}(1 \cdot 07-10 \cdot 7) \\
0 \cdot 19^{2}(0 \cdot 10-0 \cdot 37) \\
2 \cdot 72^{2}(1 \cdot 23-4 \cdot 21)\end{array}$ & $\begin{array}{l}0.28(0 \cdot 10-0 \cdot 47) \\
0.44^{1}(0 \cdot 14-0 \cdot 75) \\
3 \cdot 00^{1}(0 \cdot 69-13 \cdot 1) \\
0 \cdot 17^{1}(0 \cdot 08-0 \cdot 37) \\
2 \cdot 49^{1}(0.92-4 \cdot 07)\end{array}$ & $\begin{array}{l}0.27(0.17-0.36) \\
0.62(0.31-0.92) \\
1.30(0.44-3.85) \\
0.23(0.09-0.57) \\
3.07(1.69-4.45)\end{array}$ \\
\hline $\begin{array}{l}\text { Haemopexin } \\
\text { Complement } C^{\prime} 3 \\
\beta \text {-lipoprotein } \\
\text { Transferrin }\end{array}$ & $\begin{array}{l}\mathrm{g} / 1 \\
\mathrm{~g} / 1 \\
\mathrm{au} / 1 \\
\mathrm{~g} / 1\end{array}$ & $\begin{array}{l}\text { Yes } \\
\text { No } \\
\text { Yes } \\
\text { Yes }\end{array}$ & $\begin{array}{c}0.96^{1}(0.51-1 \cdot 81) \\
0.86(0 \cdot 18-1 \cdot 53) \\
128^{2}(57-287) \\
1.85^{1}(0.98-3.48)\end{array}$ & $\begin{array}{c}0.96(0.44-2.11) \\
0.85(0.15-1.55) \\
151(84-272) \\
1.68^{1}(0.81-3.48)\end{array}$ & $\begin{array}{c}0.77(0.51-1 \cdot 15) \\
0.75(0.40-1 \cdot 10) \\
151(73-312) \\
2.29(1.52-3.43)\end{array}$ \\
\hline $\begin{array}{l}\text { IgG } \\
\text { IgA } \\
\text { IgM }\end{array}$ & $\begin{array}{l}\mathbf{g} / 1 \\
\mathbf{g} / 1 \\
\mathbf{g} / 1\end{array}$ & $\begin{array}{l}\text { Yes } \\
\text { Yes } \\
\text { Yes }\end{array}$ & $\begin{array}{c}10 \cdot 6(4 \cdot 3-25 \cdot 9) \\
1 \cdot 11(0 \cdot 18-6 \cdot 90) \\
0.43(0 \cdot 15-1 \cdot 25)\end{array}$ & $\begin{array}{c}11 \cdot 1(4 \cdot 8-25 \cdot 6) \\
1.43(0 \cdot 49-4 \cdot 20) \\
0.53(0 \cdot 19-1 \cdot 52)\end{array}$ & $\begin{array}{c}10.3(6 \cdot 5-16 \cdot 2) \\
1 \cdot 32(0 \cdot 53-3 \cdot 25) \\
0.58(0 \cdot 22-1 \cdot 50)\end{array}$ \\
\hline No. of observations & & & 42 & 36 & 78 \\
\hline
\end{tabular}

Table I Mean values \pm 2 SD of 19 serum proteins in patients with Crohn's disease, patients with ulcerative colitis, and in a matched control group

Significant deviations from normal mean are listed. Logarithmic transformation was used for statistical analysis in 12 of the 19 proteins. ${ }^{1} \mathbf{P}<0.01$.

${ }^{2} 0.01>P>0.05$.

${ }^{3} \mathrm{au}=$ Arbitrary units. A few proteins were quantitated in arbitrary units. Their approximate absolute concentrations per 100 au were (Schultze and Heremans, 1966): $a_{1}$-lipoprotein $=2 \mathrm{~g} / \mathrm{l}$, easily precipitable glycoprotein $=0 \cdot 1 \mathrm{~g} / \mathrm{l}, \alpha_{1}$-antichymotrypsin $=0 \cdot 25 \mathrm{~g} / \mathrm{l}, \beta$-lipoprotein $=2 \cdot 5 \mathrm{~g} / \mathrm{l}$. 
14 to 66 . Before the study five patients had been operated on, while colectomy was undertaken in another 11 patients after the study. According to the criteria of Dearing et al (1969), the activity of the disease was quiescent in five, mild in eight, moderate in 15, and severe in eight cases. All patients were followed regularly either at the outpatient clinic or during readmission. The period of observation after the serum protein studies was from six months to two years during which time the course and the effect of treatment were registered.

\section{Results}

Table I gives the mean values and range (mean \pm 2 SD) of 19 serum proteins in the control material and in patients with Crohn's disease or ulcerative colitis. No significant difference in the serum protein pattern existed between Crohn's disease and ulcerative colitis. The variances of the concentrations of orosomucoid, $a_{1}$-antitrypsin, $a_{1}$-antichymotrypsin, haemopexin, complement $C^{\prime} 3$, transferrin, and IgG were significantly higher $(P<0.01)$ in patients in both disease groups than in the control material. Significant positive correlations were found between the concentrations of proteins which altered in the same way during disease, eg, proteins which increased (orosomucoid, $a_{1}$-antitrypsin, $a_{1}$-antichymotrypsin, haptoglobin), proteins which decreased (prealbumin, albumin, $\alpha_{2}$-HS glycoprotein, transferrin), and proteins which displayed only minor changes (easily precipitable glycoprotein, Gc protein, caeruloplasmin, $\alpha_{2}$-macroglobulin, haemopexin, complement $C^{\prime} 3$ ).

Furthermore, a significant negative correlation existed between serum albumin on the one hand and orosomucoid and $a_{1}$-antichymotrypsin on the other.

IgG and $\operatorname{IgA}$ were positively correlated in ulcerative colitis $(P<0.01)$ as well as in the control material $(\mathrm{P}<0.001)$. IgM was positively correlated to IgG in ulcerative colitis $(\mathrm{P}<0.001)$ and in the controls $(\mathrm{P}<0.01)$ but not in Crohn's disease. No correla-

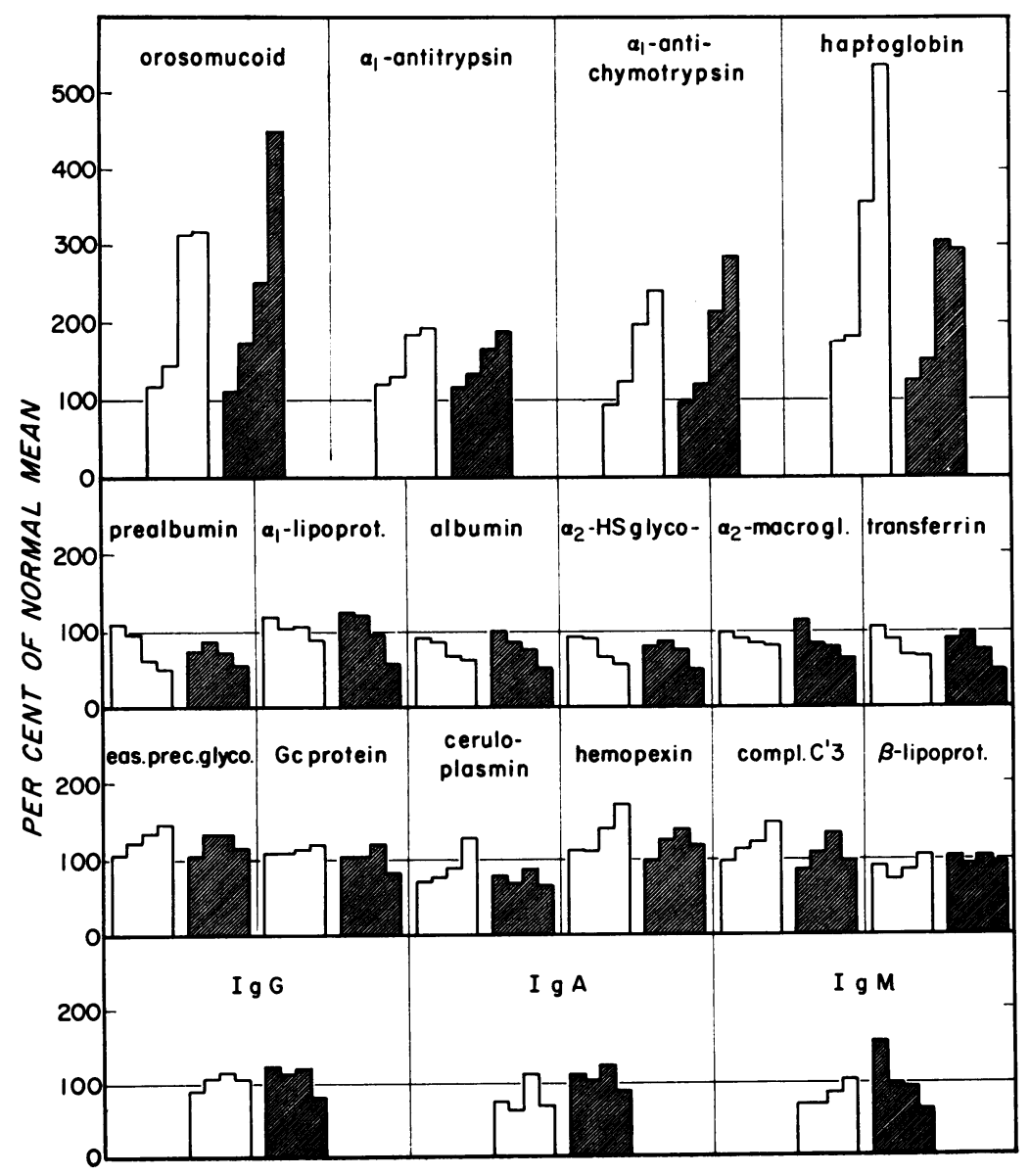

Fig. 1 Serum concentration (\% of normal mean) of 19 serum proteins related to the clinical grade of disease activity in Crohn's disease and ulcerative colitis. (eas. prec. glyco. = easily precipitable glycoprotein.) 
tion existed between $\operatorname{IgM}$ and $\operatorname{IgA}$ in any of the three groups.

\section{CLINICAL ACTIVITY}

Figure 1 relates the activity of the two diseases to the serum level of the 19 proteins studied. Increasing severity was, in both diseases, associated with increasing serum levels of orosomucoid, $a_{1}$-antitrypsin, $a_{1}$-antichymotrypsin, and haptoglobin, and with falling levels of prealbumin, $a_{1}$-lipoprotein, albumin, $\alpha_{2}$-HS glycoprotein, $\alpha_{2}$-macroglobulin, and transferrin.

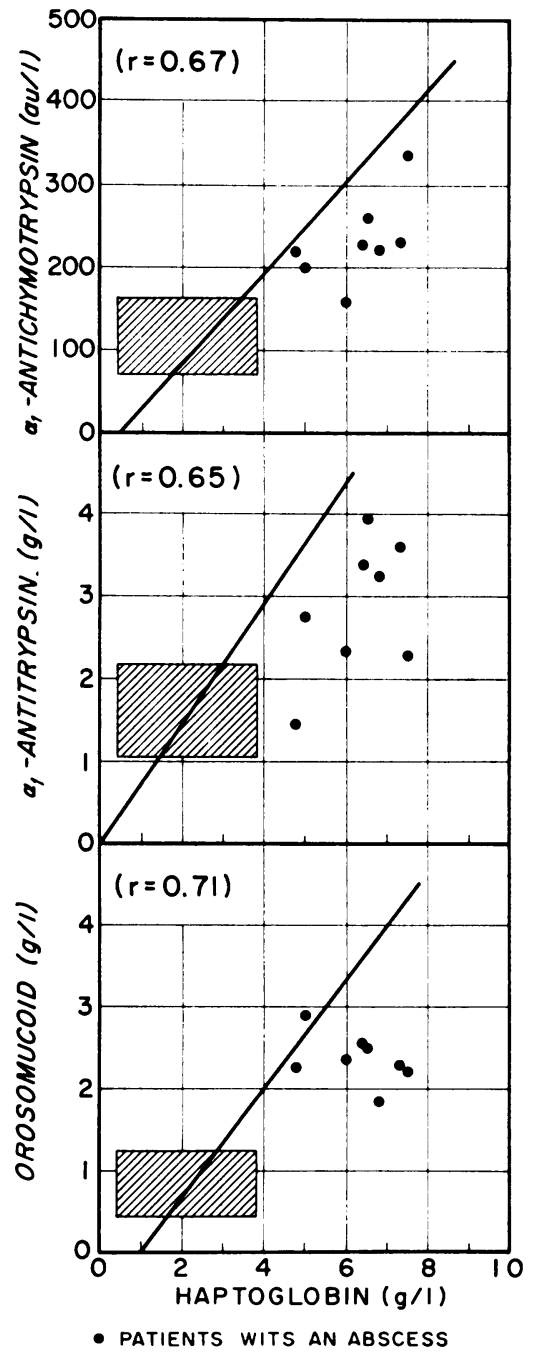

Fig. 2 Correlation between haptoglobin and other acute phase proteins ( $\alpha_{1}$-antichymotrypsin, $\alpha_{1}$-antitrypsin, orosomucoid) in Crohn's disease in 34 cases without an abscess and in eight cases with an abscess or suppurative fistula. Shaded area = normal range; 0 = patient with abscess or suppurative fistula.
In Crohn's disease, a high degree of activity resulted in a rise in the mean values of easily precipitable glycoprotein, caeruloplasmin, haemopexin, and complement $C^{\prime} 3$. In ulcerative colitis high activity depressed IgG, IgA, and IgM. The elevation of haptoglobin in eight patients with Crohn's disease who had either an abscess or suppurative fistula was remarkably high compared with the

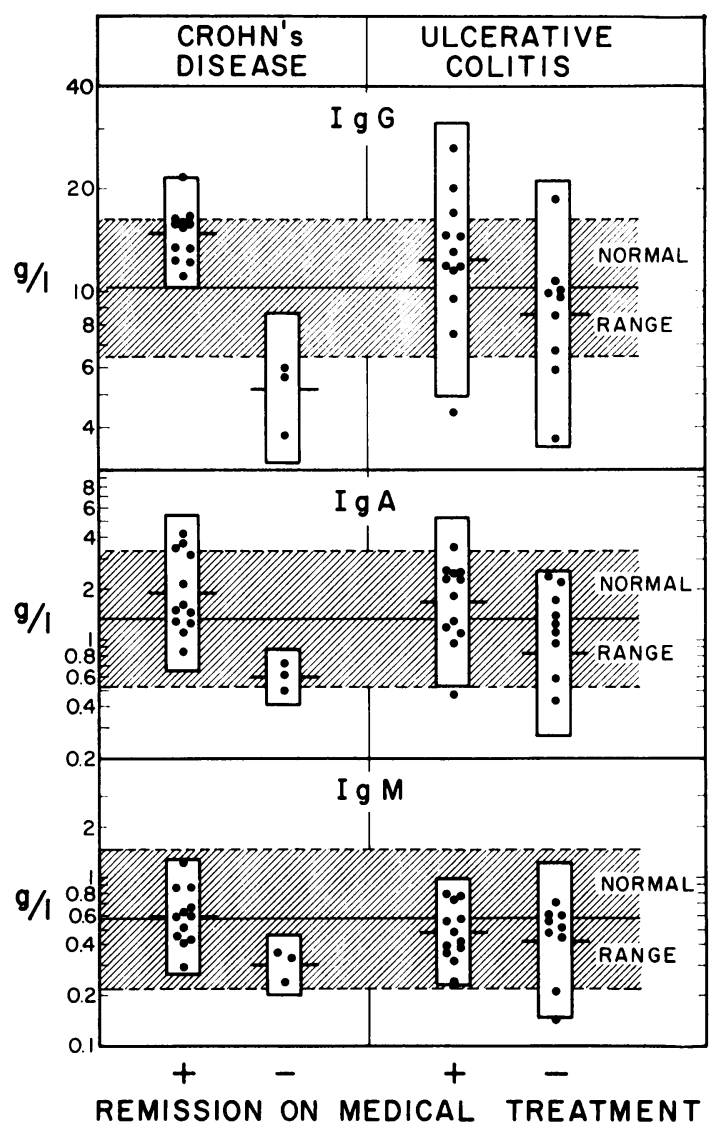

Fig. 3 Immunoglobulin levels (mean $\pm 2 S D$ ) in patients with no operation who had moderate to severe Crohn's disease or ulcerative colitis. The patients were divided into two groups: one responded favourably to treatment (prednisone and/or salicylazosulphapyridine), the second did not, and ultimately required surgery. Mean $\pm 2 S D$ of a matched control material is also shown. The $y$ axis is logarithmic.

elevation of orosomucoid, $\alpha_{1}$-antitrypsin, and $\alpha_{1}$ antichymotrypsin (Fig. 2).

One patient with terminal ileitis was seen immunochemically to lack IgA in serum and on immunofluorescence microscopy to lack IgA containing plasma cells in proximal jejunal mucosa. 


\begin{tabular}{|c|c|c|c|c|c|c|c|}
\hline \multirow[t]{2}{*}{ Group } & \multirow[t]{2}{*}{ No. of Subjects } & \multicolumn{6}{|c|}{ Serum Protein Concentration } \\
\hline & & Albumin & $a_{1}-$ Globulin & $a_{2}-$ Globulin & $\beta-G l o b u l i n$ & a-Globulin & Total \\
\hline
\end{tabular}

Table II Algebraic sum of immunochemically determined serum proteins within the traditional paper electrophoretic protein fractions in Crohn's disease, ulcerative colitis, and control subjects

\section{DURATION OF DISEASE}

Whether the history was short (less than two years) or long seemed to influence only the serum levels of IgG and IgA. In Crohn's disease the deviation from the normal mean of IgG and IgA was $+15 \%$ and $+4 \%$ respectively in 22 cases with a short history, and $-5 \%$ and $-31 \%$ respectively in 20 cases with a long history. Conversely, in ulcerative colitis of short duration (19 cases) the deflection of $\mathbf{I g G}$ and IgA was $-5 \%$ and $-15 \%$ respectively, and in 17 cases with a longer history $+27 \%$ and $+42 \%$ respectively.

\section{PROGNOSTIC VALUE OF SERUM PROTEIN \\ LEVELS}

The immunoglobulin levels in both moderate and severe cases were compared with the levels in patients who had not undergone surgery and who were successfully treated with salicylazosulphapyridine and/or steroids and in patients in whom medical treatment failed and surgery was undertaken (Fig. 3). IgG, IgA, and IgM were all significantly lower $(P<0.001)$ in patients with Crohn's disease which did not respond to medical treatment. The same trend was noticed in patients with unresponsive ulcerative colitis. However, the difference was statistically insignificant.

\section{IMMUNOCHEMICAL AND PAPER ELECTRO-}

PHORETIC ANALYSIS

Simple addition of the individual serum proteins (Table I) within the traditional fraction obtained by paper electrophoresis yielded the results listed in Table II. In agreement with previous results of paper electrophoretic studies, both patients with Crohn's disease and patients with ulcerative colitis had low total protein and serum albumin and an increase in $\alpha_{1^{-}}$and $\alpha_{2}$-globulin; $\beta$ - and $\gamma$-globulin were not significantly changed.

\section{Discussion}

The introduction of immunochemical methods for the detection and quantitation of serum proteins represents a major advance in the study of protein change in disease. In contrast to paper electrophoresis, immunochemical analysis permits accurate estimations of individual, chemically well defined proteins. In the present study the serum concentration of 19 proteins was determined in two chronic inflammatory conditions, Crohn's disease and ulcerative colitis, which almost invariably influence serum protein patterns. The paper electrophoretic changes, ie, hypoalbuminaemia and elevated $\alpha_{1}$ $a_{2}$-globulin, paralleled the results of immunochemical studies, which showed a decreased albumin level and raised concentrations of the 'acute phase reactants', ie, orosomucoid, $a_{1}$-antitrypsin, $a_{1}$-antichymotrypsin, and haptoglobin, which constitute a large fraction of $a_{1}$ - and $a_{2}$-globulins. Thus, immunochemical studies yield the explanation why the heterogeneous groups of $a_{1}$ and $a_{2}$-globulins are elevated.

\section{ALBUMIN}

The decreased albumin in Crohn's disease and ulcerative colitis is an almost consistent phenomenon and explains the associated hypoproteinaemia, since albumin is the major fraction of serum protein. Hypoalbuminaemia is due to intestinal protein loss, which usually is moderate (Bendixen et al, 1968). In contrast to non-inflammatory, protein-losing conditions like intestinal lymphangiectasia, albumin synthesis is rarely increased or values are even low normal. Therefore, fairly severe hypoalbuminaemia may be seen in the presence of slight protein loss.

\section{IMMUNOGLOBULINS}

The most remarkable finding was that the mean level of the serum level of IgG, IgA, and IgM did not deviate significantly from the normal mean; nor did the mean values differ in Crohn's disease or ulcerative colitis (Table I). However, this does not mean that the metabolism of immunoglobulins is unchanged. Turnover studies with radioiodinelabelled IgG and IgM have demonstrated profound changes in the metabolism of these two immunoglobulin classes in both diseases (Bendixen et al, 1968 and 1970; Jensen, Goltermann, Jarnum, Weeke, and Westergaard, 1970). The degradation rate and 
the synthetic rate were both increased, in particular in Crohn's disease, in which it could be shown that the increased degradation was probably not, or only to a minor degree, due to abnormal intestinal protein loss. The synthetic rate was increased up to 10 times the normal mean. Nevertheless, the serum concentration was usually normal because the increased synthetic rate was matched by the simultaneous increase of degradation rate. This illustrates the limited value of a concentration level for a given serum protein in a given disease. The concentration is nothing else than the result of the dynamic equilibrium between breakdown and synthesis of the protein.

Like de Dombal (1968 and 1969) we found that low serum $\gamma$-globulin corresponding to low serum IgG was present in several active cases of ulcerative colitis, and that a higher serum level of IgG seemed to indicate a better prognosis in ulcerative colitis. The same observation was made in the present cases of Crohn's disease, but the number of observations are too few for definite conclusions.

\section{ACUTE PHASE REACTANTS}

The concentration of acute phase reactants, ie, orosomucoid, $a_{1}$-antitrypsin, $a_{1}$-antichymotrypsin, haptoglobin, was increased in similar ways in Crohn's disease and ulcerative colitis. The increase paralleled the grade of activity. The finding is unspecific in so far as similar changes occur in other inflammatory conditions (Weeke, Weeke, and Bendixen, 1971). Patients with Crohn's disease complicated by suppurative fistulas or abscesses had a more pronounced elevation of haptoglobin than the other 'acute phase reactants'. It is noteworthy that patients in this group also have an extraordinarily high degradation rate of IgM (Jensen et al, 1970).

\section{THE REMAINING PROTEINS}

Complement $C^{\prime} 3$ was normal or slightly increased in ulcerative colitis (Fletcher, 1965) and in Crohn's disease which does not suggest that any complementconsuming antigen-antibody reaction takes place in either of the diseases. The decreased level of $a_{2}$ macroglobulin during active disease might be due to an increased fibrinolytic condition in the two diseases.

We conclude that the serum proteins are markedly changed in Crohn's disease and ulcerative colitis. However, since the alterations are very similar in the two diseases and correspond to the protein changes due to inflammations outside the gastrointestinal tract, they are of minor importance in the diagnosis of Crohn's disease and ulcerative colitis. Nonetheless, the concentration of certain proteins ('the acute phase reactants' and the immunoglobulins) yields useful information about the grade of activity of the disease and seems to be of prognostic value.

This study was supported by grants from the Købmand i Odense Johann og Louise Weimann født Seedorff's legat, and F. L. Smidth and Co., A/S's jubilæumsfond and P. Carl Petersens fond.

\section{References}

Bendixen, G., Jarnum, S., Søltoft, J., Westergaard, H., Weeke, B., and Yssing, M. (1968). IgG and albumin turnover in Crohn's disease. Scand. J. Gastroent., 3, 481-489.

Bendixen, G., Goltermann, N., Jarnum, S., Jensen, K. B., Weeke, B., and Westergaard, H. (1970). Immunoglobulin and albumin turnover in ulcerative colitis. Scand. J. Gastroent., 5, 433-441.

Bicks, R. O., Kirsner, J. B., and Palmer, W. L. (1959). Serum proteins in ulcerative colitis. I. Electrophoretic patterns in active disease. Gastroenterology, 37, 256-262.

Bicks, R. O., Kirsner, J. B., and Palmer, W. L. (1959). Serum proteins in ulcerative colitis. II. The effects of therapy correlated with electrophoretic patterns. Gastroenterology, 37, 263-267.

Cooke, W. T., Fowler, D. I., Cox, E. V., Gaddie, R., and Meynell, M. J. (1958). The clinical significance of seromucoids in regional ileitis and ulcerative colitis. Gastroenterology, 34, 910919.

Dearing, W. H., McGuckin. W. F., and Elveback, L. R. (1969). Serum $a_{1}$-acid glycoprotein in chronic ulcerative colitis. Gastroenterology, 56, 295-303.

de Dombal, F. T. (1968). Prognostic value of the serum proteins during severe attacks of ulcerative colitis. Gut, 9, 144-149.

de Dombal, F. T. (1969). Prognostic value of estimating serum proteins in cases of ulcerative colitis in remission. Gut, 10, 491-496.

Fletcher, J. (1965). Serum complement levels in active ulcerative colitis. Gut, 6, 172-175.

Jensen, K. B., Goltermann, N., Jarnum, S., Weeke, B., and Westergaard, H. (1970). IgM turnover in Crohn's disease. Gut, 11, 223-228.

Schultze, H. E., and Heremans, J. F. (1966). Molecular Biology of Human Proteins, vol. I. Nature and Metabolism of Extracellular Proteins. Elsevier, Amsterdam.

Soergel, K. H. and Ingelfinger, F. J. (1961). Proteins in serum and rectal mucus of patients with ulcerative colitis. Gastroenterology, 40, 37-46.

Weeke, B. (1968). Quantitative estimation of human immunoglobulins following carbamylation by electrophoresis in antibodycontaining agarose. Scand. J. clin. Lab. Invest., 22, 107-111.

Weeke, B. (1969): Immune chemical determination of serum albumin, transferrin, IgG, IgA and IgM. (Danish). Ugeskr. Lag., 131, 1423-1428.

Weeke, B. (1970). The serum proteins identified by means of the Laurell crossed electrophoresis. Scand. J. clin. Lab. Invest., 25, 269-275.

Weeke, B., and Bendixen, G. (1969). Serum immunoglobulins and organspecific, cellular hypersensitivity in ulcerative colitis and Crohn's disease. Acta med. scand., 186, 87-91.

Weeke, B., Weeke, E., and Bendixen, G. (1971). The variation in twenty-one serum proteins before and after renal transplantation. Acta med. scand., 189, 113-118. 